\title{
Hunters, rangers, cougars, and jaguars: human and nonhuman territories at the Argentine-Brazilian border, 1960s-1990s
}

\section{Cazadores, guardabosques, pumas y jaguares: territorios humanos y no humanos en la frontera argentino-brasileña, años 1960-1990}

\author{
Frederico Freitas ${ }^{i}$ \\ ' Assistant Professor of History, North Carolina State University. \\ Raleigh - NC - USA \\ orcid.org/0000-0002-8662-0627 \\ freitas.history@gmail.com
}

Received on 14 Jan. 2021.

Approved on 20 June 2021
FREITAS, Frederico. Hunters, rangers, cougars, and jaguars: human and nonhuman territories at the ArgentineBrazilian border, 1960s-1990s. História, Ciências, Saúde-Manguinhos, Rio de Janeiro, v.28, supl., dez. 2021, p.59-79.

Abstract

This article aims to understand the role of territorial practices in the interaction between human and nonhuman animals. It focuses on the Iguazú and Iguaçu national parks, established by Argentina and Brazil in the 1930 s as nature reserves bisected by an international boundary. In a setting where human-made boundaries overlay natural boundaries, qualitatively different spatial practices clash in the territorial encounters between cougars, jaguars, and humans. The article demonstrates how changes in the border practices of park officials, hunters, and big cats reshuffled the terms of these encounters. The article assesses when, where, and how these encounters between rangers, poachers, and big cats took place, showing how felids challenged the spatial placement and taxonomical categories attributed to them by humans.

Keywords: big cats; animal history; national parks; conservation; borderlands.

Resumo

El artículo enfoca los parques nacionales de Iguazú e Iguaçu, establecidos por Argentina y Brasil en la década de 1930 como reservas naturales divididas en dos por una frontera internacional. En un entorno donde los límites creados por el hombre se superponen a los límites naturales, las prácticas espaciales cualitativamente diferentes chocan en los encuentros territoriales entre pumas, jaguares y humanos. El artículo demuestra cómo los cambios en las prácticas fronterizas de los funcionarios del parque, los cazadores y los grandes felinos reorganizaron los términos de estos encuentros. El artículo evalúa cuándo, dónde y cómo tuvieron lugar estos encuentros entre guardabosques, cazadores y grandes felinos, mostrando cómo los felinos desafiaron la ubicación espacial y las categorías taxonómicas que los humanos les atribuyeron.

Palabras clave: grandes felinos; historia animal; parques nacionales; conservación; fronteras. 


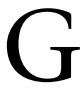
eographer Robert D. Sack (1986), in his book Human territoriality, proposes territoriality as a specifically human strategy for deploying power. In the author's view, humans employ territoriality when they use spatial boundaries to control other humans' behavior within a demarcated area. Territoriality is ubiquitous: humans use territoriality at different scales and in diverse situations. For example, when prohibiting young children from entering a specific room in the house (e.g., a home office), a parent employs territoriality. The parent defines a delimited area - the office - and announces that entering that area would result in a reprimand. These same principles work at different scales. In the case of a national park, for example, park officials and legislation define a spatial perimeter to be protected and limit the categories of people and kinds of behaviors they allow within those boundaries. Park regulations allow outside humans to enter a national park to visit areas open for tourism, but ban them from hunting and exploiting the park's natural resources. In Sack's understanding, the rules that constitute human territories such as national parks define whether specific behaviors ought to be considered proper or out of place. In this sense, every place has a territorial dimension structuring it. Sack $(1986,1997)$ also notes that territoriality can result from conscious choice. As a deliberate strategy, it is a geometric form in which power can be wielded in human societies.

Sack argues that his definition of territoriality describes an exclusively human phenomenon (Sack 1997, p.275, note 11). As a strategy, not an instinct, territoriality can be deployed by humans whenever the situation renders it advantageous. It is also culturally specific, since the barriers, signs, taboos, mores, and edicts that support the construction of territories are particular to each society. However, nonhuman animals complicate this picture of an exclusively human territoriality, as they also employ territorial control as "an efficient means to fulfill their basic needs for food, security and reproduction" (Gold, 1982, p.45-47). Nonhuman animals use territoriality to manage intra-species density over a determined area in order to guarantee access to food or mating or as a strategy to evade predators. Various nonhuman animal species produce territories - from insects to birds to fish to mammals. They use "classification," "communication," and "enforcement" to produce territories in ways that are comparable to how humans employ territoriality. They use a species-based criterion to classify the beings subjected to territorial sanctions - e.g., by banning members of their species or closely related ones. They expand the array of senses used to demarcate territorial boundaries, as they not only use sight (e.g., scrape marks), but also employ sound (e.g., bird songs) and scent (e.g., urine and scat). Finally, they also enforce their territories in different ways, including the actual patrolling of delimited areas or pathways, which always entail the threat of violent altercations with members of their species (Emmons, 1997, p.163-169).

Territoriality, either human or nonhuman, is commonly conceptualized as an intraspecies phenomenon. Geographers think of territories as a human construct that affects other humans. Zoologists identify animal territories as a behavioral strategy directed towards individuals or groups in the same species or closely related ones. My interest here, however, lies in the instances where human and nonhuman territories overlap. I argue that, instead of being analogous but distinct phenomena, human and nonhuman territorialities reside at different points on the same continuum. The spatial dimensions of human and animal territoriality follow a similar geographic logic. As situated strategies of control, they 
inhabit a shared world. Thus, human and nonhuman territorialities overlap spatially in ways that create opportunities for various inter-species interactions.

This paper looks at how certain large species of felids - the cougar (Puma concolor) and the jaguar (Panthera onca) - interact with human territories when constructing their hunting and mating territories. The spatial patterns of large felids such as cougars and jaguars are particularly useful for investigating how human and nonhuman territorialities overlap for a few reasons: many (but not all) species of large felids establish hunting and mating territories that penetrate human ones; their somatic and spatial scale is congruent to the scale of human activities at the local level; and the capacity of some individuals to opportunistically prey on humans (particularly young ones) guarantees a type of interaction that transgresses the boundaries of human spaces (Emmons, 1997, p.163-169; Gullo, Lassiter, Wolch, 1998). ${ }^{1}$

However, before we advance further into the analysis of territories, we must revisit the role of "placing" in understanding human-animal spatial relations. Geographers have used the idea of "placing" as a lens to understand the spatiality of human-animal relations. They have noticed that the social construction of space places nonhuman animals in categories with material and symbolic ramifications (Philo, Wilbert, 2000; Urbanik, 2012; Buller, 2014). As Buller (2014, p.233-234; highlights in the original) argues, "the terms 'wild,' 'domestic,' 'companion,' 'feral,' 'pet,' 'invasive,' [and] 'alien' all contain implicit - and sometimes explicit - spatial categorizations," which are ultimately reflective of how humans conceptualize the space they inhabit. For example, in urban settings, animals are considered "pets" as long as they are perceived as belonging in the space of human households. "Pets" are not to be found inside zoos or national parks. Placing implies an expectation of a place to be physically inhabited by animals, separating the species allowed to co-habit human spaces from others that should be kept at bay. In the wild, placing envisions habitats and niches that harbor particular species. As Philo and Wilbert point out, placing also implies a taxonomical place - the position occupied by a specific species in the classificatory schemata produced by different human societies. The impulse to classify animals in various categories is pervasive in human cultures - it can be found in hunter-gatherer cultures, the Bible, and modern biology. It establishes animals' local standing vis-à-vis other animals (in a space populated by contingent, usually impermeable categories) and their distance from humans.

Placing provides a valuable framework for understanding human-animal relations in a physical space. Nevertheless, it also creates blind spots. When looking at nonhuman animals through their placing in human societies, one tends to see challenges to their placing as transgressions. The agency of individual nonhuman animals is presented as subordinate to that of humans - animals react after being acted upon. I propose here that territoriality be added to the toolbox of humanists to understand how humans and nonhuman animals interact in space. Recognizing the territories constructed by nonhuman animal species opens a window to a series of spatial interactions where agency is not exclusive to humans. It also offers the possibility of understanding animal actions beyond being solely a reaction to human initiatives. Different groups of animals are territorial in different ways, and in some cases the overlapping between human and nonhuman territories is more significant than in others. 


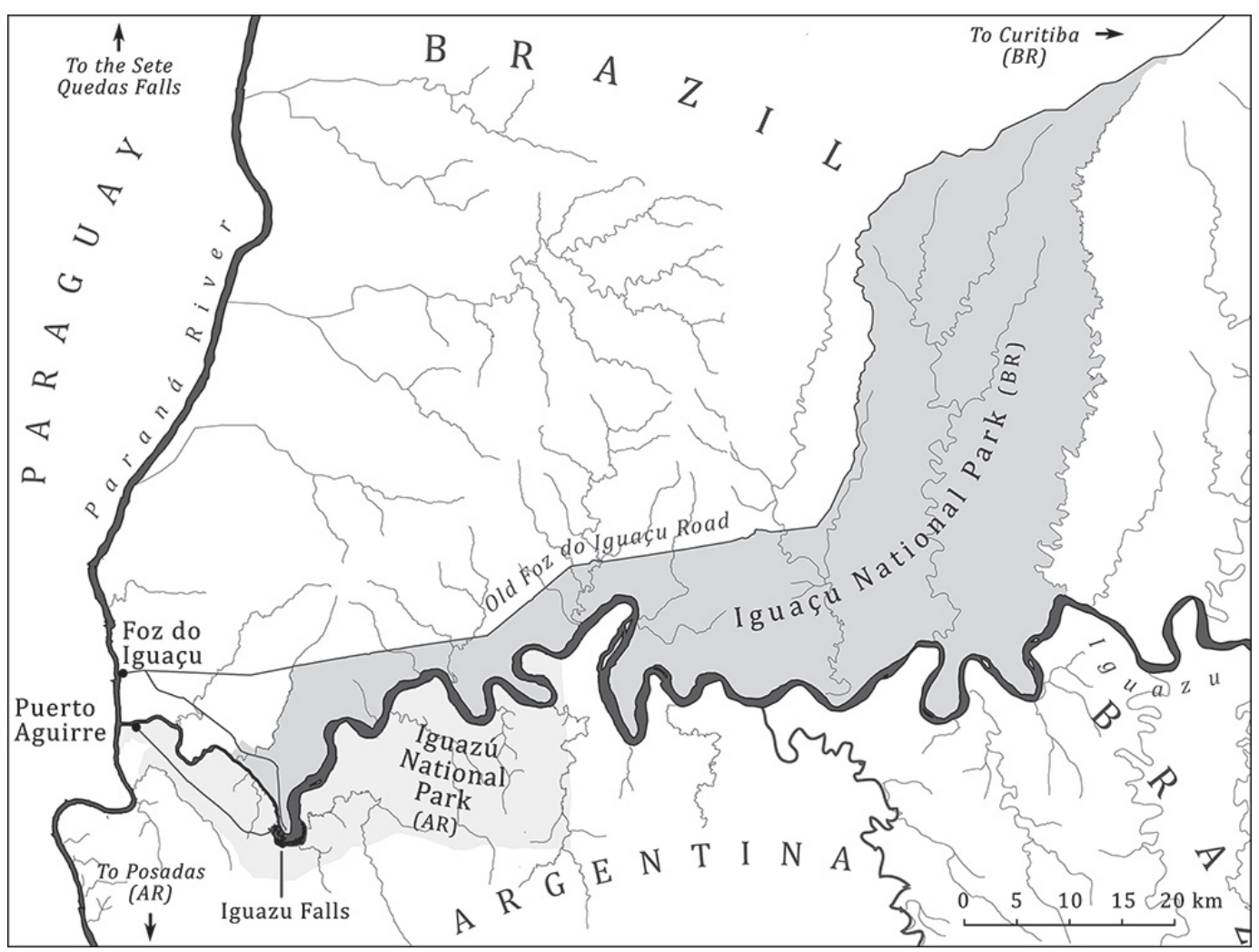

Figure 1: Iguazú National Park (Argentina) and Iguaçu National Park (Brazil), c. 1960 (elaborated by the author)

\section{A confluence of boundaries}

This article examines the spatial interactions between humans, jaguars, and cougars at the Iguazú National Park (Parque Nacional Iguazú) located in Argentina, and the Iguaçu National Park (Parque Nacional do Iguaçu) situated across the international boundary in Brazil. The two parks were created in the 1930s by Argentina and Brazil to protect and control the famous Iguazu Falls and adjacent expanses of subtropical forest. They stretch along the valley of the Iguazu River, which serves as the boundary between Argentina and Brazil before flowing into the Paraná River (see Figure 1). As two of the first national parks implemented in Latin America - the Argentine park was created in 1934, and the Brazilian park in 1939 - they provide an example of how decades of change in environmental paradigms has influenced the people and landscape affected by national park boundaries. Likewise, as borderland parks, both the Argentine and the Brazilian parks provide us with a privileged perspective of the rapid environmental and socio-spatial changes taking place on the two sides of this border region.

The two parks also provide an opportunity to study the spatial overlap between humans and big cats ${ }^{2}$ because they are located at the intersection between different types of territorial boundaries. First, there are the park boundaries. As some of the first national parks established in Latin America in the 1930s, the two Iguazu parks predate 
the large-scale colonization of the Upper Paraná River banks initiated in the 1950s. Thus, the two parks, which harbor pre-settlement forests, successfully prevented their territories from being transformed by agriculture and forestry like other sections along this border. Yet, in a sense, they also produced wilderness. Indeed, as a manifestation of the national governments' move to control territory, the parks made possible a landscape of wild nature that, today, would not exist otherwise (Neumann, 2004). Present-day satellite imagery provides evidence of the role of the parks in both preserving and producing nature. They show the stark relief of the contours dividing the subtropical forests inside the parks from the mosaic of croplands outside them (Freitas, 2021). Another set of boundaries, those separating the many national spaces in this borderland, adds another variable to the analysis. The two Iguazu parks were established in a borderland area known locally as the Triple Frontier, between Argentina, Brazil, and Paraguay (see Figure 1). During colonial times, this section of the Paraná River Basin was disputed by the Portuguese and Spanish crowns. By the late 1800s, international treaties had settled the boundaries between the inheritor nation-states. Nethertheless, disputes over transboundary issues continue to this day at this porous borderland. The two Iguazu parks are divided by the international boundary separating Brazil and Argentina and are managed independently by each country. Thus, the international border dividing the parks adds a geopolitical layer to the lives of the humans and nonhuman animals inhabiting the region. Finally, the boundaries found inside the two national parks complicate a view of protected areas as homogenous spaces of pristine nature. Zoning defines these internal territories, separating park sections open for visitation from those where tourism is banned. The main attraction of the two parks is Iguazu Falls, a 2.7 kilometer-wide complex system of cataracts shared by Brazil and Argentina. Every year, millions of tourists visit the two national parks to see the natural monument. ${ }^{3}$ However, the area open for visitation in each park encompasses only a tiny fraction of the lands surrounding the falls - less than five percent of the parks' aggregate area. A vast territory of over 200,000 hectares is set apart for strict nature preservation, banning visitation to preserve old-growth stretches of Atlantic forest (ICMBIO 2018; APN, 2017).

Therefore, the two protected areas are defined by the overlapping territories of conservation and land use, park and non-park lands, and different national jurisdictions. If one accepts Edward Casey's (2007) proposition that boundaries are the primary vehicle of historical action - where the relationship between place and event intensifies - then one can use the case of the Iguazu parks to reveal a different dimension in the relationship between space and history. This new dimension can be found in the multiple territories established by the individuals of the several animal species that inhabit the parklands, which exist in a tense relationship with the overlapping, human-made territories. In the case of big cats, the space of the two Iguazu Parks has been chosen as hunting and mating grounds by both cougars and jaguars. As we will see in this article, individuals from both species have constructed territories that expand beyond the many boundaries set by humans, defying their placing as wildlife restricted to the parks' preserved "natural habitats." Since before the establishment of the parks in the 1930s, jaguars and cougars have played a prominent role in the environmental history of the border area. They were 
coveted by hunters of all types as the prime game species. They were hated and feared by the local population for their role in preying on domestic animals. They were valued by scientists and park administrators for their role as apex predators. Moreover, they proved to be historically significant for the challenges they posed to the territorial regime implemented by humans in this area. The remainder of this article discusses three instances in which big cats challenged the places and territories created by humans at the Argentine and Brazilian national parks. The three cases help us understand how, when establishing the two Iguazu national parks as nature preservation spaces, humans had to contend with the overlapping territories created by nonhuman animals.

\section{Challenging human territories}

The first recorded case of a big cat attacking humans in the two national parks occurred in the early 1960s. The attack happened when officials at the two Iguazu parks started pressuring Buenos Aires and Brasília to remove the thousands of settlers who lived inside the two national parks. When Argentines and Brazilians created the parks in the 1930s, they envisioned them as tools for developing and controlling their respective sides of the border (Freitas, 2021). This attitude by park officials allowed the establishment of settlements inside the two national parks. By the 1960s, however, the tide had changed. A growing consensus in both countries began to envision national parks as natural spaces free of people. Soon, authorities in the two parks moved to evict the settlers living inside the two protected areas. The following cases reveal how park officials used the collision between big cats and settlers to justify evicting the latter from the national parks. What was initially construed as a big-cat intrusion into territories where humans dwelled became encroachment of jaguar territory by settlers.

In 1962, settlers living inside the Iguazú National Park in Argentina began reporting a jaguar prowling around their dwellings. For years, settlers who lived close to the Iguazu Falls inside the Argentine park had raised animals for subsistence, a fact criticized by the conservationists working at the Argentine National Park agency. In one report, a national park official, Juan Daciuk (1961, 1962), concluded the domestic animals introduced by settlers were displacing the native wildlife - the park's natural inhabitants. However, in the eyes of a jaguar, the animals brought in by settlers meant an abundance of prey. About 350 humans, over 1,000 chickens, and about 100 cows, pigs, and dogs lived in an area of cleared forest adjacent to the Iguazu Falls. It was just a matter of time until a feline predator started breaching the park's many human dwellings. By April 1962, a jaguar had already killed several domestic animals kept by settlers inside the Iguazú National Park, including chickens, dogs, and a calf. Park rangers decided to act after the jaguar entered the house of Aurelio Dominguez, age 55, who worked maintaining an airstrip built inside the park. The jaguar injured Dominguez as he attempted to prevent the animal from entering his house to catch a dog. National park rangers eventually killed the jaguar. In his report, park ranger José Gorgues justified the killing on the threat the animal posed to the children living in the area. However, the killing was controversial because the rangers roasted the 
dead jaguar and shared the meat with locals (see Figure 2). Officials at the national park agency in Buenos Aires were appalled by the news and demanded an explanation from the rangers involved (Protección de la Naturaleza, 1962, p.1-5).
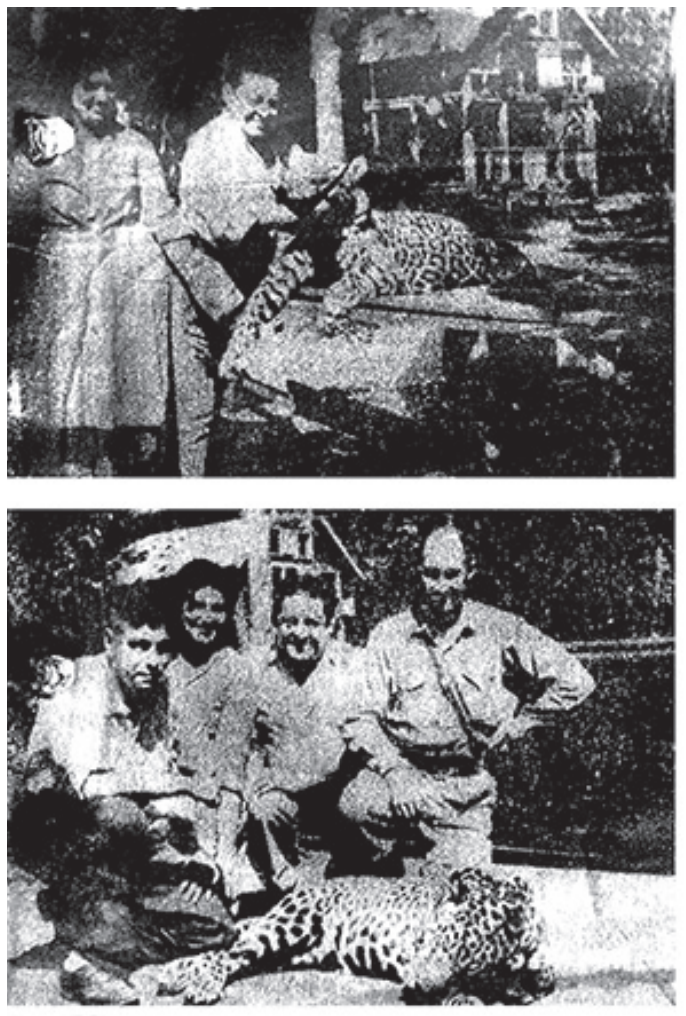

ARRIBS: JUNTO IL TIGRE CAZIDO, IL SESOR ADELATMO IFRAN Y SU ESPOSA. EN TA OTIA IOTO JOSE GENGUES ICL

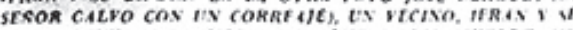
SORA. JUVTO A T.A FIERA I LA QUF $C$ HO VIRNTE. UK

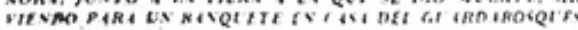

\section{MATAN A UN TIGRE, LO ASAN Y LO COMEN: MEJOR QUE LECHON}

\begin{abstract}
I $N$ la ditima quincena de abril $y$ en diferentes lugares, 2 entre las Cataratas del Iguazú y Puerto Iguazú, algunos tigre comenzaron a rondar los ranchos de los po. bladores. A pocos metros del campo de aviación de Ca taratas, en una pensibn, ya habian comido mis de volnte gallinas, hirieron también al perro que custodiabn la casa Por estas razones un fotbgrafo de apellido Garefa y el agronte policial Acosta montaron guardia en una pieza donde aquel of hospedabs. Dejaron semiabierta una ventana esperando que de lado más tupido dol monte apareclera la fiera, suponiendo que el ladrido del perro los alertaria. Cansados do esperar so que daron dormidos $y$ a las 8 de in madrugada del 1 ' de mayo des pertaron de improviso ante ruidos extraños. De pronto un tigre amenazante penetro en la habitacion woguldo del perro. Garels le disparb con el winchester sin dar en el blanco y fue derrlbado por la fiera. Perdis la linterna y quedaron en la oseurldad. El animal atacs al fot6grafo provocíndole un desgarrón en el bruzo izquierdo y mordiéndole una mano. García lo aplie $\delta$ varios cula. tatos $y$ logro desprenderso, introducíndose on la cocina, ya herido. Cerraron la puerta y el tigre abandono la habitación saltando por la ventana.

Al dia siguiente, en el kllometro 11 entre el Puerto y Cats. ratas, el guardabosques Joś Gergues, quien haco cinco afios mats a otro tigre que se encuentra embalsamado on el museo de Iguazb, subido a un árbol con un compañero, esperb la llogada de la fiera y al verla llegar le bizo an disparon eon el wincheater hiriéndola. Poco despué descendieron y de dos tíros on la cabe. za le dieron muerte. Por la noche, en casa del guardabosques, compatieros y vecinos prepararon al tigre, lo pusieron sobre us asador y se dieron un banquete. Aseguran que su carne es ma exquisita que la del lechon. Ahora Gergues se dispone a olimi. nar otros tigres que siguen atacando terneros o to que encuen. tran, impulsados por el hambre. El sefor Adolaida Itrín, domi. ciliado on Puerto Igunzti (Misionea) ha tenido la gentlieza de envisernos los datos be este sureso $;$ has dos fotogratias que usompatian ta note.
\end{abstract}

Figure 2: "They killed, roasted, and ate a jaguar: it tasted better than suckling pig". Ahora, May 15, 1962 (Protección de la Naturaleza, 1962)

The jaguar's killing in 1962 reveals the complex overlaying of the different territorialities of humans and nonhumans in the park. First, there is the jaguar's territory, determined by its hunting range. Settler presence in the park brought in an abundance of domestic animals, which led the jaguar to expand its territory into the area inhabited by humans. Of course, jaguars do not recognize boundaries as defined by human law, customs, and culture. Second came the territory of the settlers who lived inside the national park and struggled to transform an area set aside for tourist visitation into a space for production and reproduction. Third, there was the territory of unconfined domestic animals whose domain was loosely defined by their co-existence with humans. Finally, there was the territory of the national park itself, whose administration started considering settlers as intruders and jaguars as the rightful dwellers of the park. National park ranger José Gorgues reproduced this idea in his report 
by referring to the settlers as squatters, ignoring the fact that many had been invited to live in the park by previous park directors.

The ordeal reveals the tension between the vision of the national park officials, who began to see the park as a space for nonhuman animals, and the rangers' experience enforcing the park regulations on the ground. To the latter, it was clear that people took precedence over jaguars. Still, ranger José Gorgues was cunning enough to yield to the expectations of conservationists in the higher echelons of the national park structure. In this way, he argued he had offered the jaguar a "trial" to determine if the animal had really "gotten a taste for human flesh." Gorgues explained that the "trial" was carried out moments before the killing, as he "tested" the animal's disposition towards humans (Protección de la Naturaleza, 1962, p.1-5). ${ }^{4}$ On the night of the killing, he and another park ranger left a half-eaten dog carcass as bait and climbed up a tree to wait for the animal. When the jaguar appeared, they pointed their flashlights at the animal's eyes to grab her attention. According to Gorgues, the jaguar's decision to attack them instead of running away sealed her destiny, and the animal was shot and killed by the two rangers. Gorgues claimed they acted in "self-defense:" in contrast to the cautious behavior expected from most jaguars, the animal demonstrated a ferocious disposition towards humans, showing they had no other option but to kill the jaguar. Still, Gorgues failed to mention that the chosen hunting method - ambushing from atop a tree perch - was widely practiced in the region and bore the expectation of an animal's violent reaction. Armed with rifles, hunters in the area used makeshift tree platforms to surprise and kill difficult animals such as jaguars, not to capture them alive (Muello, 1930, p.73-76, 90, 106-108, 120; Dras, 9 Oct. 1940; Laferrère, 1945, p.169-172; Intendencia Iguazú, 1948).

When the Argentine Iguazú National Park was first established in the 1930s, park authorities allowed the killing of jaguars and other animals they considered "game." The first director of the Argentine National Park agency, Exequiel Bustillo, envisioned sport hunting and fishing as crucial aspects of the country's new national parks (see Figure 3). At the time, the Iguazú National Park authorities would liberally kill jaguars to supply museum dioramas with specimens or present politicians with hides (Bustillo, 1968, p.331360; Amarante, 16 Sep. 1937). The 1960s, as exemplified by the backlash from the jaguar roasted by park rangers, represents the beginning of an inflection point. Throughout Latin America, governments adopted a ban on the trade of jaguar hides and prohibited jaguar hunting (Rabinowitz, 2014, p.77-88). Legislation and common sense converged to agree that preserving big cats was one of the goals of a national park. However, jaguars' incursions into settler areas inside parks tested the limits of the growing consensus on jaguar conservation. For park rangers working on the ground, killing big cats was justified when they invaded spaces not reserved for wildlife. By the 1970s, as things continued to change, settlers became the ones seen as an invasive presence inside protected areas. That was when park authorities on both sides of the border launched programs to remove settlers from park lands. 


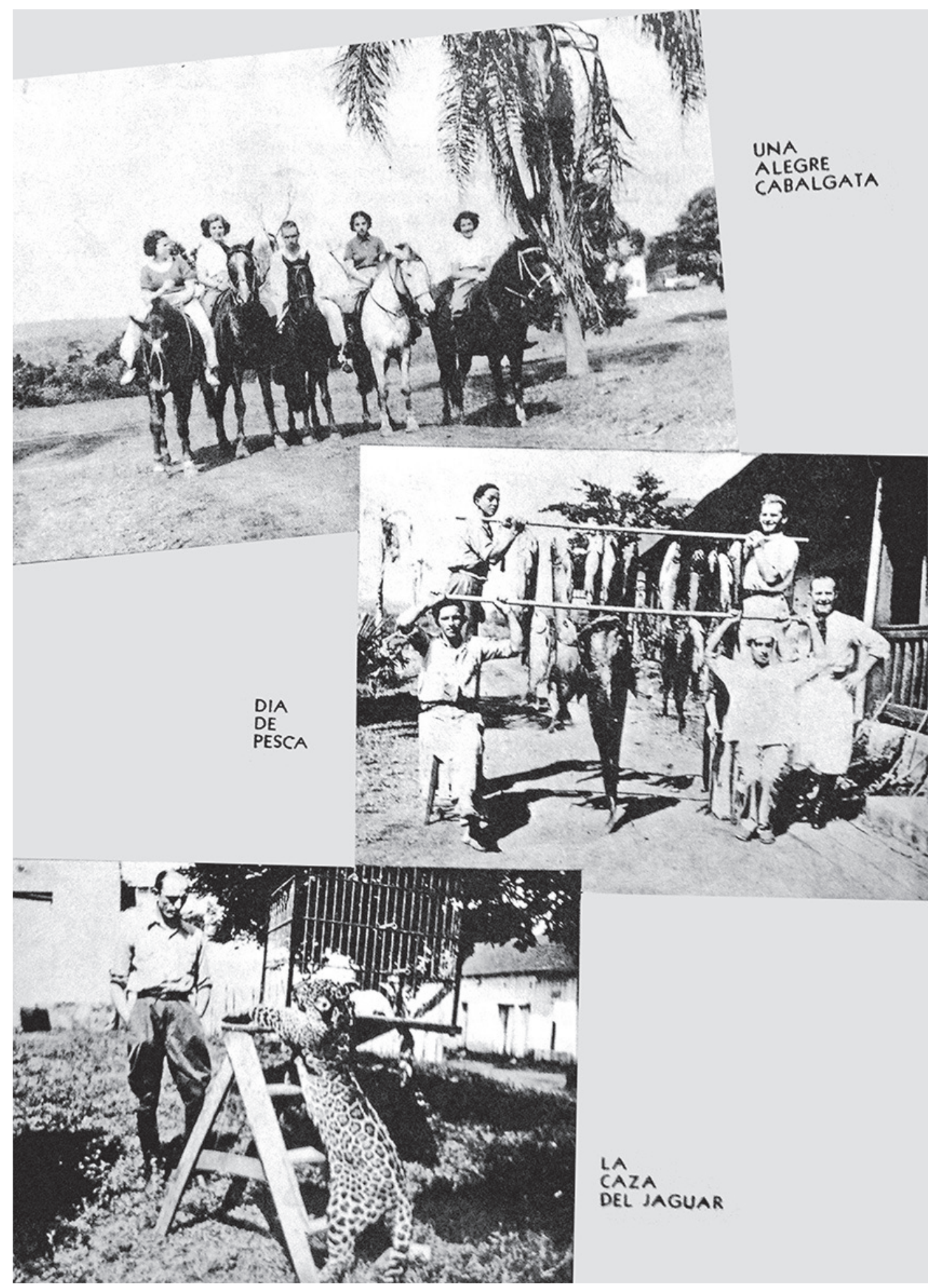

Figure 3: Promotional material produced in the early days of the Argentine national park advertised "jaguar hunting" as an activity for tourists in the region (Dirección de Parques Nacionales, 1940) 
An example was the case of Juan Hoppe, the last settler to leave the Argentine national park in the 1970s. Hoppe was a Polish immigrant who had been living inside the park since 1953. In 1971, park authorities seized a jaguar hide from Hoppe's guesthouse after he had offered it for sale to tourists visiting the Iguazu Falls. According to Hoppe, he had killed the animal in August 1970 after the jaguar had taken eleven of his calves, as well as "a cow, eight dogs, a pig, and many fowl." Despite Hoppe's losses, park authorities framed the jaguar's killing as part of a series of offenses that jeopardized Hoppe's standing as a park dweller. According to them, he had failed to mention the presence of a prowling jaguar to park authorities in 1970, had killed the jaguar without authorization, had hidden the fact from park authorities, and was illegally offering the jaguar hide for sale to tourists. Hoppe was fined 500 pesos for the jaguar's death - the punishment provided in the park legislation. The settler tried to improve his standing by sending the park director a letter arguing that he had had no choice but to kill the animal, who had entered his house and threatened his wife - a fact he had failed to mention in his official testimony. Hoppe would only leave the park in 1979, but the unauthorized killing of jaguars would become one of the justifications park authorities used to remove him and other settlers from parklands. To park authorities, the presence of settlers and their domestic animals inside the Iguazú National Park in Argentina was a lure for big cats like jaguars and cougars, who extended their hunting territories to the area occupied by humans. As they reconceptualized the park spatially as a habitat for endangered wildlife, removing settlers from the protected area became imperative (APN, 1960, p.136-144; Intendente Iguazú, 1971; Asesoria Juridica..., 1979).

\section{Overlapping human and nonhuman territories}

In the region of the two Iguazu parks, big cats such as jaguars establish territories that may vary from 8,000 to 60,000 hectares (Morato et al., 2016; Paviolo et al., 2016; Morato et al., 2018; McBride, Thompson, 2018, 2019). With an aggregate area of about 220,000 hectares of preserved Atlantic forest, the two national parks have enough space to harbor up to twenty-four adult individuals - assuming jaguars choose to limit their territories to park boundaries. In the Brazilian Iguaçu National Park (162,912 hectares), estimates of the jaguar population found that about 64 adults were living in the park in the mid-1990s (Crawshaw Jr., 1995, p.88). Current estimates are that 28 adult animals live in the same park today (Gonzales, 30 Oct. 2020). Some of this decline might be due to poaching inside the park. Nevertheless, there is also ample geographical and historical evidence that jaguars have established territories that go beyond the boundaries of the parks. The jaguars killed in 1962 and 1970 met their fate after expanding their territories to prey on domestic animals raised by settlers living inside the parks. Their cases are well documented because they entered the territories of settlers whose standing inside the protected areas was being challenged by park administrators. Less often reported, but probably more frequent, were cases when jaguars and cougars encroached on the farms 
and ranches outside the national parks. It was only in the 1990s, with the beginning of the first scientific surveys on the big cats' behavior and population at the Iguaçu National Park in Brazil, that the phenomenon started to be systematically recorded. Around this time, colonization outside the park had reduced the protected area to an oasis of forest surrounded by a sea of cropland (Freitas, 2021). The disappearance of forests outside the park also contributed to increasing the number of violent encounters between farmers and big cats and between the big cats themselves. Like humans, jaguars and cougars are territorial animals, a fact demonstrated by Peter Crawshaw, one of the first biologists to study the behavior of big cats in the area of the parks in the early 1990s. ${ }^{5}$ Crawshaw investigated jaguars' spatial and hunting patterns in the park using tracking collars and documented intra-species competition for territory involving several animals (Crawshaw Jr., 1995). One of them was M13, an eighteen-month male jaguar who struggled for months to establish his territory in this region.

M13 was born in the peninsula of the Iguaçu National Park in March 1990 (see Figure 4, inset). After he reached young adulthood, he started his journey across the border region, searching for his own territorial space. As seen in Figure 4, he crossed to Argentina in September 1991, where he stayed for two months before returning to Brazil for a couple of days. In late November, M13 was back in Argentina, where he started traversing the Puerto Iguazú peninsula and cutting through the Argentine park's boundaries. Something was pushing him forward, probably a combination of a territorial dispute with other jaguars (and maybe humans) and the search for food. In December 1991, M13 reached the Paraná River banks, at the border between Argentina and Paraguay, and crossed it at a point where the mighty river is 400 meters wide. In Paraguay, the young jaguar found himself confined to a small patch of forest surrounded by farmland. Seventeen days later, he had returned to his original area in Brazil, where he probably clashed with the older jaguar who already claimed the area for himself (Crawshaw Jr., 1995, p.84). He remained in the area until early January, but was then chased away to a distant zone in the Brazilian park, thirty-three kilometers away from his birth area.

M13 traversed several human-made borders in all his wanderings, including park, municipal, and national boundaries, with all the risks those crossings entailed (see Figure 4). After moving to the northeastern section of the Brazilian national park, M13 stopped roaming, a sign he might have encountered a zone without competition from other jaguars. However, in late May, he found himself in the crosshairs of a poacher and his fifteen-year-old son, who waited to ambush white-lipped peccary atop a tree stand inside the park. In his quest to find a territory free of jaguar competitors, M13 stumbled upon the territory of poachers. He was killed, and his body was found by Crawshaw with his tracking collar at the poacher's house, on the Iguazu river bank outside the national park. 


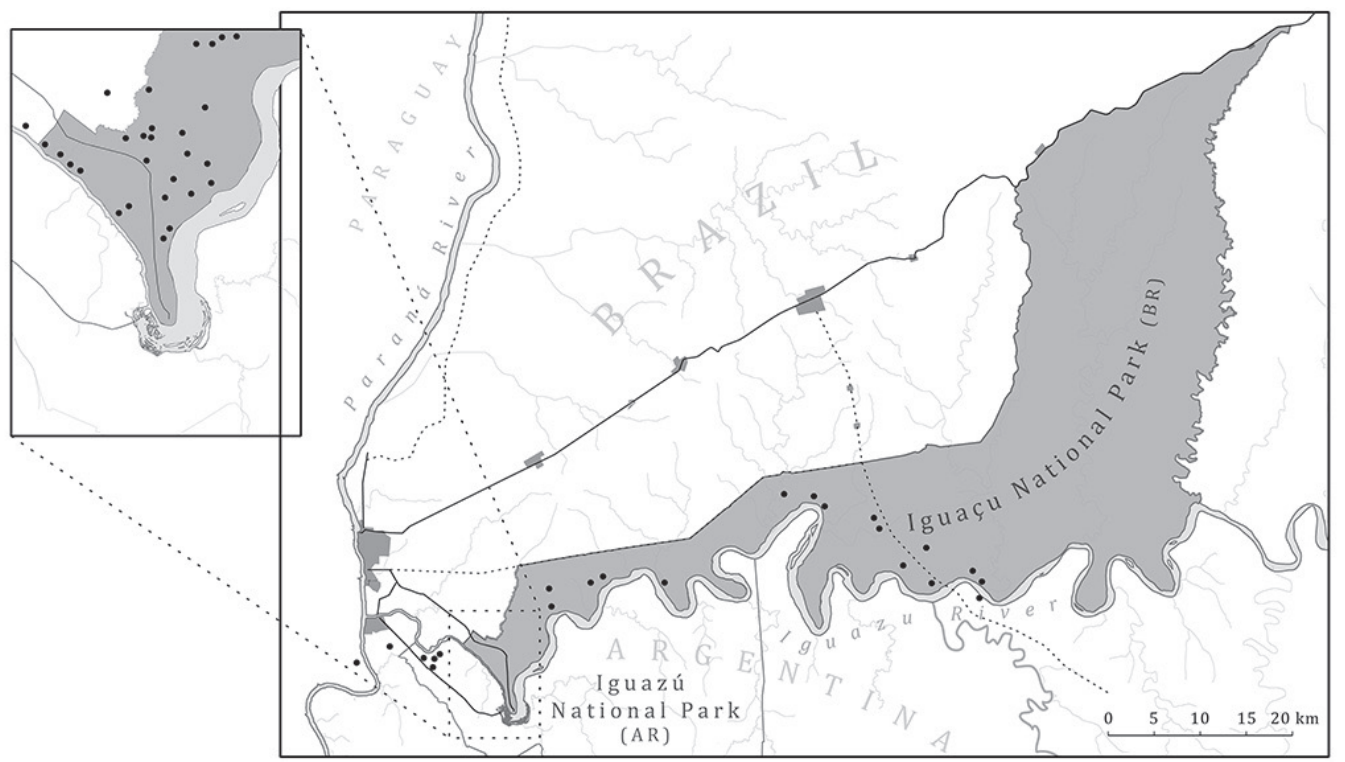

Figure 4: Radio locations of subadult male jaguar M13, April 19, 1991-May 26, 1992 (elaborated by the author, based on a map by Crawshaw Jr., 1995).

White-lipped peccaries (Tayassu pecari) comprised the bulk of jaguars' prey in Iguaçu about $77 \%$ of their diet. It is unclear how much of M13's moving was caused by his search for peccary sounders. Most likely, a lot. When hunting peccaries, jaguars faced competition from their kind, as well as from humans and cougars, the other two species that preyed on the swine. Indeed, peccaries were one of the main species targeted by poachers in the region. Peccaries were also regularly killed by farmers retaliating against the invasion of croplands by sounders coming out of the park. In his study, Crawshaw Jr. (1995, p.126130) calculated the density of peccaries and jaguars in the park, the percentage of peccary meat in the jaguar diet, and the number of peccaries killed by humans inside and outside the park. The swine, like the jaguars, did not observe park boundaries. He concluded that they would soon become extinct in the park and jaguars would have to switch to smaller animals. Indeed, 13 years later, white-lipped peccaries had already disappeared from the Brazilian park, and jaguars and cougars had changed their dietary preferences to encompass other mid-sized animals like brockets (Mazama genus), capybara (Hydrochoerus hydrochaeris), and the smaller collared peccary (Dicotyles tajacu). ${ }^{6}$ Jaguars also increasingly preyed on livestock outside park boundaries, including cattle. However, the Cougars in the region never began targeting large domestic ungulates, in contrast to other areas in the Americas where they are known to prey on cattle. These peculiarities demonstrate the differences in hunting culture and patterns in big cat populations (Azevedo, 2008; Conforti, Azevedo, 2003; Polisar, Maxit, Scognamillo, 2003).

Jaguars and cougars also preyed on other domestic animals, particularly chickens, dogs, and pigs, which were the most common in the region. Predation on domestic animals was a significant cause of complaints among farmers in the region. The parks were designed to keep nonhuman animals inside and human animals outside, but they failed in both 
regards. Jaguars such as M13 were oblivious to park boundaries, despite their usually being delimitated by a road or a river - water is not a challenge for jaguars (Morato et al., 2018). Fencing the park was not an option either, as cats easily traversed the few sections isolated with barbed wire. Indeed, an experiment in the 1990s attempted to measure the efficacy of electric fences in deterring jaguar attacks on pigs raised by local farmers. The electric fence proved utterly ineffective, as the animals quickly learned to avoid it. Jaguars managed to enter the pig pens, kill pigs and drag them away, despite the electric fence in place (Schiaffino, Malmierca, Perovic, 2002). Circumventing electric barriers demonstrates the capacity of jaguars and cougars to challenge the territories established by humans. People use signs, boundaries, and fences to communicate potential trespassers of the existence of a bounded territory. However, these boundary markers were insufficient to contain the movements of jaguars and cougars. Indeed, the attempt to utilize electric shocks as a clear, non-verbal somatic strategy for communicating to animals the spatial restrictions of a border failed miserably with jaguars. Like the poachers who ignored the signs of park boundaries, jaguars and cougars refused to comply with the different human borders. ${ }^{7}$

\section{Historicizing animal territories}

In the 1990s, the work carried out by zoologists such as Crawshaw contributed to changing the attitudes of park authorities and locals in terms of their treatment of big cats. As wildlife conservation discourse took hold, scientists and park officials began to refer to charismatic species such as jaguars and cougars as belonging in the parks. As a result, locals on both sides of the border began to contact park authorities to deal with animals trespassing into their properties. The growing collaboration between scientists and park officials also resulted in the adoption of new protocols to capture and relocate predators who ventured outside the parks (Crawshaw Jr., 1995, p.90-91). This was exemplified in January 1995 when leaders at the Yryapu, a Guarani indigenous community located outside the Argentine Iguazú National Park, requested the national park director's help to capture a jaguar prowling in the area. The jaguar had killed three dogs and had even entered a house. It was the same animal that park officials had already captured and released inside the park a year before. The Argentine park director contacted Peter Crawshaw in Brazil, who, along with three rangers, installed a tree platform in the area and left a carcass of one of the killed dogs as bait while waiting throughout the night. Crawshaw employed the same ambushing technique used by Argentine park rangers in 1962 to kill the jaguar who penetrated territories of settlers inside the park. However, instead of killing the animal, the scientist managed to shoot the jaguar with a tranquilizer. Then, they took the jaguar to a nearby wildlife reserve maintained by the Itaipu dam in Brazil. After that, they relocated the animal to a zoo in the Province of Chaco, in Argentina. Contrast the animal's final destination with the fate of the jaguar hunted by Argentine park rangers in 1962. In the 1990s, the placement of jaguars on lists of endangered species demanded their relocation to new spaces for animal protection and confinement (Giacchino, 1 Jan. 1995). 
Scientists like Crawshaw recognized that, in the case of jaguars and cougars, there was a series of factors that led them to ignore park boundaries and prey on livestock. These big cats occupied large territories not contained by park boundaries, particularly in the Brazilian park, whose southwestern section had only a narrow band of land (see Figure 1). The park boundaries also lacked effective deterrents to prevent the big cats from roaming outside them - protected areas are not zoos. It would be impractical and prohibitively expensive to isolate hundreds of hectares with jaguar-proof fences. Once big cats learned about the easy-to-catch food source located just outside the park, there was nothing that would stop them from attempting to prey on it. Learned predation patterns are transmitted through jaguar and cougar generations, as females with cubs teach their offspring to hunt. The impact of livestock predation by jaguars on low-income farmers was considerable, and the latter would usually retaliate. Zoologists saw conflict over cattle to be one of the main reasons for jaguar mortality, despite the secondary place occupied by livestock production in the farms surrounding the Iguazu parks at the time (Crawshaw Jr., 1995, p.132-133; Crawshaw Jr., Quigley, 2002, p.223-236; Polisar, Maxit, Scognamillo, 2003).

The work of zoologists such as Crawshaw served to position jaguars and cougars as animals belonging in the two national parks' forested landscapes. Still, the animals repeatedly defied such placement with incursions into territories of human agricultural and livestock production outside the parks. There was, however, another level of placement affecting the big cats, one that worked within the boundaries of the two national parks. Jaguars and cougars belonged in the parks, but inside them, they were expected to stay away from certain areas: i.e., the sections visited by tourists around the falls and the zones inhabited by park personnel. By the 1990s, the two parks no longer harbored settlers within their territories, but a small group of park officials and their families still lived there. However, Jaguars and cougars did not always observe the zones of dwelling and visitation humans had established inside the parks. That would lead to a tragic event when a big cat attacked a human child in the late 1990s.

On September 21, 1997, a cougar attacked and killed twenty-month-old boy Ignacio Terán, the son of a park ranger in the Iguazú National Park in Argentina. ${ }^{8}$ Terán was playing with his brothers and other children where rangers lived with their families inside the park, near the Iguazu Falls, when a cougar came out of the bushes, attacked Terán, and dragged him back to the woods. The toddler's body was found two hours later, at 8pm, in the bushes, just a hundred meters from the attack location. The tragedy mobilized the park's entire staff in a hunt to, as one park ranger stated, "capture the individual responsible for the attack" (Malmierca, 17 Oct. 1997). With the help of biologists from Argentina and Brazil, rangers spent the night setting cage traps in the park in the hope of capturing the culprit. On the following day, they found a cougar wandering near the lower pathways leading to the waterfalls. The cougar, a young (two- to three-year-old) female individual, was shot and killed. This 1997 cougar faced a fate similar to that of the 1962 jaguar, as national park rangers killed both. Different, however, was the fate of the animal's body. Instead of being eaten, the 1997 cougar had its body sent for autopsy to find evidence of the boy's body in the cat's digestive system. 
A first autopsy revealed no trace of the boy's body or clothes in the cougar's digestive tract. Hence, there was no evidence proving that rangers had killed the right animal. Several cougars had been seen close to the waterfalls in previous months, the only area open for tourist visitation. The killed cougar was recognized through a facial scar as an animal who had been seen twice before. However, at least one other cougar, a male one, had also been sighted in the area. Unsure if they had caught the right cougar, park administrators continued hunting with dogs and tranquilizer guns. Several people, including park employees and tourists, reported encounters with cougars in the following days, but the hunt continued for weeks without success. Finally, a second analysis of the material collected from the digestive tract of the female cougar discovered undeniable traces of human hair. The case was then closed (Malmierca, 14 Oct. 1997).

Although the tragedy of the boy killed by a cougar in 1997 was unprecedented, it had followed an uncommon rise of cougar sightings in the Argentine park's touristic zone. Twenty-eight occurrences had been recorded between March and September of that year. Seeing so many cougars in an area crowded with tourists was unsettling for park biologists because they believed South American cougars were shy and went to great lengths to avoid humans. Until then, there had been little record of cougars approaching tourists in the Argentine national parks, despite the country's considerable Puma concolor population, especially in the Andes. Park technicians and biologists in Argentina were aware of cougars attacking children in the United States, but they believed an attack of this type was unthinkable in Argentina. Using DNA markers of cougar individuals collected throughout the Americas, researchers in the 2000s defined six different subspecies of cougars, divided into several specific populations. These six subspecies consist of a single subspecies for the entire North American continent and five others for Central and South America. The latter group included the Eastern South American subspecies, whose range covers central and eastern Brazil and Uruguay, including the Iguazu cougars (Culver, 2010; Laundré, Hernández, 2010). Before the 2000s, the consensus among zoologists was that there were potentially as many as 32 subspecies, divided between North and South American clusters (Culver et al., 2000). In their reports on the Terán case, Argentine biologists follow this taxonomy, arguing that North and South American cougars had divergent attitudes towards human presence, making South American cougars particularly shy of humans (APN, 21 Sep. 1997; Malmierca, 14 Oct. 1997; Presidente del Directorio, 1997).

Researchers at the time thought cougars in North America were more curious about humans and human life, being more prone to consider human children viable prey. Overall, cougar attacks on humans are still rare when compared to attacks of other felids in Africa and Asia. However, they do occur. Between 1890 and 1990, there were 53 cougar attacks on humans in Canada and the United States, with $64 \%$ of the victims being children (Beier, 1991; Mattson, Logan, Sweanor, 2011; Hiller et al., 2015). Another 54 attacks occurred between 1991 and 2005 (Sweanor, Logan, 2010).

On the other hand, in South America, cougars historically avoided humans, at least according to what the zoologists who worked on the Terán case believed at the time. ${ }^{9}$ The sudden appearance of cougars not bothered by the presence of humans - one was videotaped by a tourist calmly eating prey in front of dozens of humans - was shocking to 
local scientists and park rangers. They believed that these cougars had either been born in the park, near the tourist area, or had been raised in captivity and released in the park. This would explain their lack of discomfort when close to humans. In any case, such a drastic change in a cougar's attitude towards humans, whatever the reason, points to the possibility of intergenerational cultural change (Hribal, 2007; Despret, 2014, p.23-24). Indeed, cultural transmission and variability are now widely documented in other nonhuman animals, from primates to corvids to cetaceans (De Waal, 2016). In the case of cougars, if a mother who grew accustomed to humans survived long enough to teach this new habit to her cubs, that would solidify a behavioral difference between cougar generations, revealing one aspect of big cat historicity. As historian Mahesh Rangarajan (2013, p.127) argues in his study on the historicity of lions in India, "animals too make their histories ... via interaction with humans who share their landscape." Lastly, it might be true that the perception of such nonhuman animal capacity for cultural change has a long history, as proven by the pervasive custom of killing individual felids who attack humans.

What does the idea of the different "cultures" of North and South American cougars teach us about apex predators' spatial practices? Was the attack in Iguazú an indication of intergenerational "cultural change" among cougars? That could indeed be the case. ${ }^{10}$ After all, nurture is a significant component in the life of a big cat. Cats learn how to hunt as cubs. If a mother starts to target human children, she might pass that behavior on to the next generation. Much of a cougar's behavior is learned, which explains the animal's adaptability - they are found all over the Americas, from Canada to Argentina. Cats who learned to prey on humans would inevitably extend their hunting territories into areas where other big cats would not usually venture, thus defying their placing as wildlife that belongs in wilderness areas.

\section{Defying placement through territorial practices}

As intraspecies behavior strategies employing a spatial logic, the territorial actions of humans, jaguars, cougars, and other species overlap in the physical world. Thus, the territory they construct provides a lens for analyzing interspecies relations. Nonhuman animals such as cougars and jaguars (but not only them) are particularly intentional when establishing their hunting and mating territories. Therefore, studying their territories in a way that pays attention to their logic is particularly helpful for the task of decentering human-animal stories (Johnston, 2008). In many cases, like the ones presented in this article, humans are the ones reacting to nonhuman agency (Hobson, 2007). Sometimes the reaction is then seized to serve different human goals. For example, in the first case, jaguars expanded their territories at the expense of settlers and park administrators used that expansion to justify the eviction of the settlers from park territory, thus, putting into practice the ideal of national parks devoid of human dwellings. However, as shown in the subsequent cases, big cats established their territories regardless of human boundaries, crossing park and national boundaries. When doing this, they clashed with other humans in territorial disputes over prey (e.g., livestock). In the most extreme cases, jaguars and cougars came to consider humans as prey, expanding their territories accordingly. 
The cases studied here demonstrate the different manners in which the territoriality of humans and big cats might overlap. They show the spatial agency of nonhuman animals and cast light onto how big cats' territoriality can oppose, resist, or elude human territories. ${ }^{11}$ When transgressing human-made boundaries, cougars and jaguars challenge two types of placements imposed on them by humans. ${ }^{12}$ First, they defy their position as wildlife, which bounds them to a specific and normative place vis-à-vis other animals, plants, and human societies. Second, and more importantly, they disregard their assigned geographical space. This is a physical place circumscribed by the boundaries humans set to contain what they consider wildlife. As denizens of national parks, cougars and jaguars are expected to be confined to the territories designated for them by national park policy. Therefore, big cats are not expected to cross the boundaries that delimitate spaces for human husbandry, or that designate spaces for tourists, or that separate park from non-park areas. Nonetheless, big cats have a territoriality of their own and, as such, represent a permanent challenge to the borders defined by humans.

\section{ACKNOWLEDGMENTS}

This article was generously funded by a National Endownment for the Humanities Fellowship, FEL-262061.

\section{NOTES}

${ }^{1}$ At the Iguazu borderland, the two species also shared a predilection for crepuscular and nocturnal activities. This preference could have developed both as a result of human diurnal activity patterns and in response to changes in prey behavior (Foster et al., 2013; Gaynor et al., 2018).

${ }^{2}$ This article employs the more expansive definition of "big cats" to include both the living members of the genus Panthera (e.g., jaguar) and the sole extant species of the genus Puma, the cougar.

${ }^{3}$ In 2019, about 1.6 million people visited the Argentine side of the falls inside Iguazú National Park. Across the border in Brazil, Iguaçu National Park received two million visitors. These numbers make the two parks the most visited non-urban parks in their respective countries and Latin America (Azarkevich, 2019; Agência de Notícias..., 2019).

${ }^{4}$ Between the late Middle Ages and the early nineteenth century, there were several recorded cases of formal trials of animals in Europe and the Americas (Dinzelbacher, 2002; Dopico Black, 2010; Cabral, 2014, p.90-91).

${ }^{5}$ Peter Crawshaw began his study of carnivores as an assistant to the famous German-American biologist George Schaller, working in the Brazilian Pantanal in the late 1970s. Schaller pioneered the method of studying the movements of mammals with radio transmitters in Brazil. They initiated their study in the Pantanal, but ultimately Schaller decided to leave due to the killing of jaguars by local farmers (Crawshaw Jr., 2006, 12 Dec. 2008, 29 Mar. 2010; Rabinowitz, 2014, p.89-91; Franco, Drummond, Nora, 2018).

${ }^{6}$ The collared peccary has also been classified as Tayassu tajacu, Pecari tajacu, and Pecari angulatus (Emmons, 1997, p.175-177).

${ }^{7}$ Industrialization offered humans new ways to employ pain as a territorial instrument to control the behavior of nonhuman animals - particularly, but not exclusively, in domestication. Barbed wires and electric fences are classic examples here. Eventually, territorial tools of animal husbandry ended up creeping into human uses. For example, the barbed wire first deployed to confine livestock was later used in human detention (Netz, 2012).

${ }^{8}$ To recreate this case, I used written reports and interviews with biologists and park rangers who witnessed it. Karina Schiaffino (biologist at Fundación Vida Silvestre) in conversation with the author, August 7, 2014; Justo Herrera (Iguazú National Park ranger) in conversation with the author, August 1, 2014.

${ }^{9}$ A survey on the history of human-cougar contact in Patagonia identified only one case of a human being attacked by the felid, two years after the Terán case, in 1999 (Walker, Novaro, 2010, p.97). There are also 
historical records of cougar attacks on humans in southern South America, such as the attack reported by famous Argentine explorer Francisco Moreno (1879, p.418-419) in 1876.

${ }^{10}$ Studying the case of leafcutter ants in nineteenth century Brazil, Diogo de Carvalho Cabral (2020) concludes, in a parallel fashion, that animals, in their spatial and material practices, are co-creators of landscapes initially thought of as exclusively human. In this way, whereas leafcutter ants employed nonsymbolic reason to negotiate and produce the landscape they shared with humans, big cats demonstrated an analogous capacity to adapt (e.g., by choosing to prey on human children) their own hunting territories to the reality of the evolving territorial practices of humans.

${ }^{11}$ Although the study of nonhuman animal movement through tracking devices is decades old (Benson, 2010), recent advances in GPS technology and computation suggest that animals have a much greater "capacity for navigation and cognition" than previously presumed. They routinely cross manmade borders in long-distance peregrination, thus challenging "deeply rooted ideas about place in nature" (Shah, 2021; Kays et al., 2015).

${ }^{12}$ Philo (1995) reached a similar conclusion about how certain species were rendered out of place in cities as urban spaces evolved.

\section{REFERENCES}

AGÊNCIA DE NOTÍCIAS do Paraná. Parque Nacional do Iguaçu bate recorde de visitantes em 2019. Agência de Notícias do Paraná, 6 Jan. 2020. Available at: https://www.aen.pr.gov.br/ modules/noticias/article.php?storyid=105231. Access on: 24 Sep. 2021.

AMARANTE, Julio. Letter to Exequiel Bustillo. Exequiel Bustillo papers, Legajo 3, n.3345 (Archivo General de la Nación-Argentina, Buenos Aires), 16 Sep. 1937.

APN, Administración de Parques Nacionales. Plan de gestión - Parque Nacional Iguazú, período 2017-2023. Puerto Iguazú: Intendencia Parque Nacional Iguazú, 2017.

APN, Administración de Parques Nacionales. Avistajes de Puma concolor en Area Cataracts Anteriores. Carpeta "Puma y Yaguaraté" (Biblioteca de la Delegación Regional NEA Administración de Parques Nacionales, Puerto Iguazú), 21 Sep. 1997.

APN, Administración de Parques Nacionales. Juan Hoppe to Dirección General de Parques Nacionales. Sol. una fracción de 36 has., en la cabecera pista de aterrizaje en las cataratas del Iguazú. Expediente 2148. (Archivo de la Administración de Parques Nacionales, Buenos Aires), 1960.

ASESORIA JURIDICA to Administación de Parques Nacionales. Memorandum 1147 - Informa sobre el estado de tramite del expediente judicial Servicio Nacional de Parques Nacionales c/Hoppe Juan s/desalojo que tramita por ante el Juzgado Federal Posadas, Expediente 2674 (Archivo de la Administración de Parques Nacionales, Buenos Aires), 1979.

AZARKEVICH, Erneto. Las Cataratas cierran 2019 com record de visitants y esperan un 2020 aún major. Clarín, 31 Dec. 2019. Available at: https://www.clarin.com/sociedad/cataratascierran-2019-record-visitantes-esperan-2020mejor_0_FzAVO3m2.html. Access on: 24 Sep. 2021.

AZEVEDO, Fernando Cesar Cascelli de. Food habits and livestock depredation of sympatric jaguars and pumas in the Iguacu National Park area, South Brazil. Biotropica, v.40, n.4, p.494500, 2008.

BEIER, Paul. Attacks on humans in the United States and Canada. Wildlife Society Bulletin, v.19, n.4, p.403-412, 1991.

BENSON, Etienne. Wired wilderness: technologies of tracking and the making of modern wildlife. Baltimore: Johns Hopkins University Press, 2010.

BULLER, Henry. Reconfiguring wild spaces: the porous boundaries of wild animal geographies. In: Marvin, Garry; Mchugh, Susan (org.). Routledge handbook of human-animal studies. London: Routledge, Taylor \& Francis Group, 2014. p.233-241.

BUSTILLO, Exequiel. El despertar de Bariloche: una estrategia patagónica. Buenos Aires: Editorial y Librería Goncourt, 1968.

CABRAL, Diogo de Carvalho. Meaningful clearings: human-ant negotiated landscapes in nineteenth-century Brazil. Environmental History, n.emaa058, 2020. Available at: https:// doi.org/10.1093/envhis/emaa058. Access on: 2 Dec. 2020.

CABRAL, Diogo de Carvalho. Na presença da floresta: Mata Atlântica e história colonial. Rio de Janeiro: Garamond, 2014. 
CASEY, Edward S. Boundary, place, and event in the spatiality of history. Rethinking History, v.11, n.4, p.507-512, 2007.

CONFORTI, Valéria Amorim; AZEVEDO, Fernando Cesar Cascelli de. Local perceptions of jaguars (panthera onca) and pumas (puma concolor) in the Iguaçu National Park area, South Brazil. Biological Conservation, v.111, n.2, p.215-221, 2003.

CRAWSHAW JR., Peter G. A onça pintada ainda tem chance? O Eco, 29 Mar. 2010. Available at: http://www.oeco.org.br/peter-crawshaw/23713a-onca-pintada-ainda-tem-chance. Access on: 10 Jan. 2021.

CRAWSHAW JR., Peter G. A volta do guru, 30 anos depois. $O E c o, 12$ Dec. 2008. Available at: http://www.oeco.org.br/peter-crawshaw/20385a-volta-do-guru-30-anos-depois. Access on: 10 Jan. 2021.

CRAWSHAW JR., Peter G. The history of carnivore research in Brazil. In: Morato, Ronaldo Gonçalves et al. (org.). Manejo e conservação de carnívoros neotropicais. São Paulo: Ibama, 2006.

CRAWSHAW JR., Peter G. Comparative ecology of ocelot (Felis pardalis) and jaguar (Panthera onca) in a protected Subtropical Forest in Brazil and Argentina. (PhD Dissertation) - University of Florida, Gainesville, 1995.

CRAWSHAW JR., Peter G.; QUIGLEY, Howard B. Hábitos alimentarios del jaguar y el puma en el Pantanal, Brasil, con implicaciones para su manejo y conservación. In: Medellin, Rodrigo A. (org.). El jaguar en el nuevo milenio. Ciudad de México: Ediciones Cientificas Universitarias, 2002.

CULVER, Melanie. Lessons and insights from evolution, taxonomy, and conservation genetics. In: Hornocker, Maurice; Negri, Sharon (org.). Cougar: ecology and conservation. Chicago; London: University of Chicago Press, 2010. p.27-40.

CULVER, Melanie et al. Genomic ancestry of the American puma (Puma concolor). Journal of Heredity, v.91, n.3, p.186-197, 2000.

DACIUK, Juan. Report to Direccion General de Parques Nacionales. Reactualizacion sistematica de las especies animales exibidas en el Museo del Iguazú... Folder 16, Expediente 2372 (Biblioteca Central y Centro de Documentación Perito Francisco P. Moreno, Buenos Aires), 1962.

DACIUK, Juan. Report to Direccion General de Parques Nacionales. Eleva informe tecnico ref. viage de estudios al Parque Nacional Iguazú mes de enero ppdo. Expediente 1746 (Archivo de la Administración de Parques Nacionales, Buenos Aires), 1961.
DESPRET, Vinciane. Domesticating practices: the case of Arabian babblers. In: Marvin, Garry; Mchugh, Susan (org.). Routledge handbook of human-animal studies. London: Routledge, Taylor \& Francis Group, 2014. p.23-38.

DE WAAL, Franz. Are we smart enough to know how smart animals are? New York; London: W.W. Norton \& Company, 2016.

DINZELBACHER, Peter. Animal trials: a multidisciplinary approach. The Journal of Interdisciplinary History, v.32, n.3, p.405-421, 2002.

DIRECCIÓN DE PARQUES NACIONALES. Parque Nacional Iguazu. Promotional Booklet. Buenos Aires: Ministerio de Agricultura; Biblioteca Nacional Argentina, 1940.

DOPICO BLACK, Georgina. the ban and the bull: cultural studies, animal studies, and Spain. Journal of Spanish Cultural Studies, v.11, n.3/4, p.235-249, 2010.

DRAS, Germán. La caza del jaguar en los montes de Misiones. Leoplán (Archivo Centro de Investigaciones Ecológicas Subtropicales, Puerto Iguazú), 9 Oct. 1940.

EMMONS, Louise H. Neotropical rainforest mammals: a field guide. Chicago: Chicago University Press, 1997.

FOSTER, Vania C. et al. Jaguar and puma activity patterns and predator-prey interactions in four Brazilian biomes. Biotropica, v.45, n.3, p.373-379, 2013.

FRANCO, José Luiz de Andrade; DRUMMOND, José Augusto; NORA, Fernanda Pereira de Mesquita. History of science and conservation of the jaguar (Panthera onca) in Brazil. HALAC - Historia Ambiental, Latinoamericana y Caribeña, v.8, n.2, p.42-72, 2018.

FREITAS, Frederico. Nationalizing nature: Iguazu falls and national parks at the Brazil-Argentina border. Cambridge: Cambridge University Press, 2021.

GAYNOR, Kaitlyn M. et al. The influence of human disturbance on wildlife nocturnality. Science, v.360, n.6394, p.1232-1235, 2018.

GIACCHINO, Horacio. Memo to Iguazú National Park Director. Carpeta "Puma y Yaguaraté" (Biblioteca de la Delegación Regional NEA - Administración de Parques Nacionales, Buenos Aires), 1 Jan. 1995.

GOLD, John R. Territoriality and human spatial behaviour. Progress in Human Geography, v.6, n.1, p.44-67, 1982.

GONZALES, Jenny. População de onças-pintadas volta a crescer no Iguaçu. Mongabay, 2 Mar. 
2020. Available at: https://brasil.mongabay. com/2020/03/populacao-de-oncas-pintadasvolta-a-crescer-no-iguacu. Access on: 30 Oct. 2020.

GULLO, Andrea; LASSITER, Unna; WOLCH, Jennifer. The Cougar's tale. In: Wolch, Jennifer; Emel, Jody (org.). Animal geographies: place, politics, and identity in the nature-culture borderlands. London; New York: Verso, 1998.

HILLER, Tim L. et al. Demography, prey abundance, and management affect number of cougar mortalities associated with livestock conflicts. The Journal of Wildlife Management, v.79, n.6, p.978-988, 2015.

HOBSON, Kersty. Political animals? On animals as subjects in an enlarged political geography. Political Geography, v.26, p.250-267, 2007.

HRIBAL, Jason. Animals, agency, and class: writing the history of animals from below. Human Ecology Forum, v.14, n.1, p.101-112, 2007.

ICMBIO, Instituto Chico Mendes de Conservação da Biodiversidade. Plano de manejo do Parque Nacional do Iguaçu. Brasília: ICMBIO, 2018.

INTENDENCIA IGUAZÚ. Report to Administración General de Parques Nacionales y Turismo, Expediente 5268 (Biblioteca Francisco P. Moreno, Administración de Parques Nacionales, Buenos Aires), 1948.

INTENDENTE IGUAZÚ. Report to Dirección General de Parques Nacionales. Expediente 2382 (Archivo de la Administración de Parques Nacionales, Buenos Aires), 1971.

JOHNSTON, Catherine. Beyond the clearing: towards a dwelt animal geography. Progress in Human Geography, v.32, n.5, p.633-649, 2008.

KAYS, Roland et al. Terrestrial animal tracking as an eye on life and planet. Science, v.348, n.6240, p.aaa2478, 2015.

LAFERRÈRE, Germán de. Selva Adentro. Buenos Aires: Editorial Argentina "Arístides Quillet," 1945.

LAUNDRÉ, John; HERNÁNDEZ, Lucina. What we know about pumas in Latin America. In: Hornocker, Maurice; Negri, Sharon (org.). Cougar: ecology and conservation. Chicago; London: University of Chicago Press, 2010, p.76-90.

MALMIERCA, Laura. Memo to Juan Carlos Chebez. Carpeta "Puma y Yaguaraté" (Biblioteca de la Delegación Regional NEA - Administración de Parques Nacionales, Puerto Iguazú), 14 Oct. 1997.
MATTSON, David; LOGAN, Kenneth; SWEANOR, Linda. Factors governing risk of cougar attacks on humans. Human-Wildlife Interactions, v.5, n.1, p.135-158, 2011.

MCBRIDE, Roy T.; THOMPSON, Jeffrey J. Spatial ecology of Paraguay's last remaining Atlantic forest jaguars (Panthera onca): implications for their long-term survival. Biodiversity, v.20, n.1, p.1-7, 2019.

MCBRIDE, Roy T.; THOMPSON, Jeffrey J. Space use and movement of jaguar (Panthera onca) in western Paraguay. Mammalia, v.82, n.6, p.540549, 2018.

MORATO, Ronaldo G. et al. Jaguar movement database: a GPS-based movement dataset of an apex predator in the Neotropics. Ecology, v.99, n.7, p.1691-1691, 2018.

MORATO, Ronaldo G. et al. Space use and movement of a neotropical top predator: the endangered jaguar. PlosOne, v.11, n.12, p.e0168176, 2016.

MORENO, Francisco. Viaje a la Patagonia Austral. Buenos Aires: Imprenta de La Nación, 1879.

MUELlO, Alberto Carlos. Misiones, las Cataratas del Iguazú, el Alto Paraná y el cultivo de la yerba mate. Buenos Aires: Talleres s.a. Casa Jacobo Peuser, 1930.

NETZ, Reviel. Barbed wire: an ecology of Modernity. Middletown, CT: Wesleyan University Press, 2012.

NEUMANN, Roderick P. Nature-state-territory: toward a critical theorization of conservation enclosures. In: Peet, Richard; Watts, Michael (org.). Liberation ecologies: environment, development, social movements. London: Routledge, 2004. p.195-217.

PAVIOLO, Agustin et al. A biodiversity hotspot losing its top predator: the challenge of jaguar conservation in the Atlantic Forest of South America. Scientific Reports, v.6, n.1, p.37147, 2016.

PHILO, Chris. Animals, geography, and the city: notes on inclusions and exclusions. Environment and Planning D: Society and Space, v.13, p.655681, 1995.

PHILO, Chris; WILBERT, Chris. Animal spaces, beastly places: an introduction. In: Philo, Chris; Wilbert, Chris (org.). Animal spaces, beastly places: new geographies of human-animal relations. London; New York: Routledge, 2000.

POLISAR, John et al. Jaguars, pumas, their prey base, and cattle ranching: ecological interpretations of a management problem. 
Biological Conservation, v.109, n.2, p.297-310, 2003.

PRESIDENTE DEL DIRECTORIO. Report to Instructor Sumariante. Expediente 0931 (Archivo de la Administración de Parques Nacionales, Buenos Aires), 1997.

PROTECCIÓN DE LA NATURALEZA. Report to Dirección de Parques Nacionales. Nota 119-Sol/ instrucción sumarias con motivo de versiones, de haber matado un jaguar y dado muerte a otro en Parc. Nac. Iguazú. Expediente 2026 (Archivo de la Administración de Parques Nacionales, Buenos Aires), 1962.

RABINOWITZ, Alan. An indomitable beast: the remarkable journey of the jaguar. Washington, DC: Island Press; Center for Resource Economics, 2014.

RANGARAJAN, Mahesh. Animals with rich histories: the case of the lions of Gir Forest, Gujarat, India. History and Theory, v.52, n.4, p.109-127, 2013.

SACK, Robert David. Homo geographicus: a framework for action, awareness, and moral concern. Baltimore: Johns Hopkins University Press, 1997.

SACK, Robert David. Human territoriality: its theory and history. Cambridge, UK: Cambridge University Press, 1986.
SCHIAFFINO; Karina; MALMIERCA, Laura; PEROVIC, Pablo G. Depredación de cerdos domésticos por jaguar en un área rural vecina a un parque nacional en el noreste de Argentina. In: Medellin, Rodrigo A. (org.). El jaguar en el nuevo milenio. Ciudad de México: Ediciones Científicas Universitarias, 2002.

SHAH, Sonia. How far does wildlife roam? Ask the 'internet of animals.' The New York Times, 2021. Available at: https://www.nytimes.com/ interactive/2021/01/12/magazine/animaltracking-icarus.html. Access on: 13 Jan. 2021.

SWEANOR, Linda; LOGAN, Kenneth. Cougarhuman interactions. In: Hornocker, Maurice; Negri, Sharon (org.). Cougar: ecology and conservation. Chicago; London: University of Chicago Press, 2010. p.190-205.

URBANIK, Julie. Placing animals: an introduction to the geography of human-animal relations.

Lanham, MD: Rowman \& Littlefield Publishers, 2012.

WALKER, Susan; NOVARO, Andrés. The World's Southernmost pumas in Patagonia and the Southern Andes. In: Hornocker, Maurice; Negri, Sharon (org.). Cougar: ecology and conservation. Chicago; London: University of Chicago Press, 2010. p.91-99.

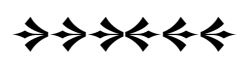

